\title{
Interaction Between Educational Approach and Space: The Case of Montessori
}

\author{
Özge İslamoğlu ${ }^{1 *}$ \\ ${ }^{1}$ Department of Interiour Architecture, Faculty of Architecture, Karadeniz Technical University, Trabzon, TURKEY
}

Received 12 September 2017 • Revised 8 October 2017 • Accepted 16 October 2017

\begin{abstract}
This study aims to emphasize that the realization of effective educational approaches depends on the design of spaces suitable for the determined philosophy, and to reveal the design decisions required by the Montessori educational approach. A three-step method was followed in the line of the aim of this study. The first step is to acquire theoretical knowledge about the Montessori educational approach. The second step is to perform a spatial analysis based on the obtained plan schedules and visual materials from the school samples that have adopted the Montessori educational approach and designed by the designers according to this approach and the final step is to bring design decisions to designers and educators in order to create educational environments for the Montessori educational approach, depending on the literature and school analysis. In the study, it is observed in Montessori educational approach that the relationship between interior and exterior spaces is very important, that the circulation spaces and classrooms are designed as flexible multipurpose spaces depending on the basic principles of freedom, socialization, and that child-scale design and natural light are extremely important for all of the areas in question. It is seen that the Montessori approach is influential on educational spaces and the presence of spaces embodying this approach has a correspondence in architecture. In this context, this study, which reveals the relationship between learning environments and learning efficiency, is considered to be a source of data for the schools to be designed in this direction.
\end{abstract}

Keywords: education, educational approaches, Montessori, design decisions

\section{INTRODUCTION}

Education is a social process providing individuals with competency and improvement under the influence of schools, which are chosen and controlled environments. The quality of this process is one of the major determinants of the economic, political and social development of the society. In this respect, the effort to think about raising human and guide the practice of education has been an important problem area in all societies since ancient times (İslamoğlu, 2014).

In parallel with the development of science and technology within the process, the concept of education has started to be considered in a wider context; the purpose and systems of education have changed; and different educational philosophies and educational approaches have emerged depending on these philosophies in the process. Each of these emerging approaches has different requirements, which have brought the schools to the agenda with different spatial characteristics and have been studied for this purpose. All of these studies emphasize that quality education and successful learning can be carried out only if the necessary context and conditions for the learning to be carried out effectively are met. For instance, Chan (1988) underscores that spatial adaptations that are appropriate for educational programs based on a particular educational approach will directly affect the quality of education, and that architecturally consciously designed spaces are a motivating and directing path in education. This is because education is the recognition of individual's real role in the establishment of the quality of his or her social life; and the place where education happens is the environment in which the individual increases 


\section{Contribution of this paper to the literature}

- This study includes readings about Montessori approach and reveals the relationship between learning environments and learning efficiency.

- This study provides guidelines for architects, designers and teachers about Montessori environments.

- This study deals with the Montessori approach from pedagogical and architectural point of view and emphasizes that

- $\quad$ schools should be planned together with educators and designers.

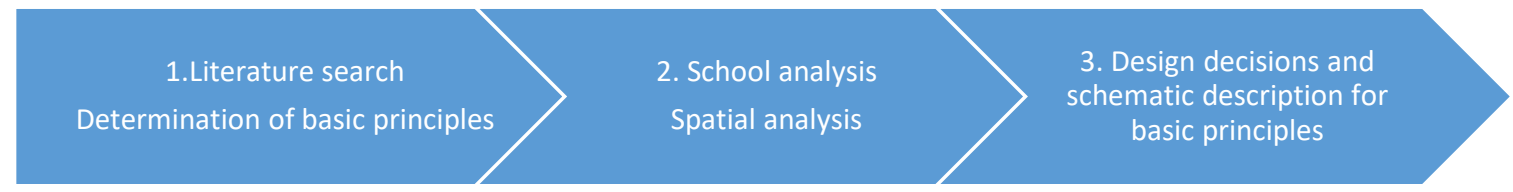

Figure 1. Work Diagram

his or her knowledge as a creative and critical person and emancipates his or her talents freely, and that place is the socio-physical environment in which children, teachers, and parents communicate. Enrichment of these environments will support children's cognitive, perceptual and motor development.

Although the concept of education seems to be outside the domain of architecture, the definition of the concept from different perspectives is quite guiding in the formation and interpretation of architectural ideas. Criticisms in the basic education reform programs in many developed countries are not only about technical, economic, and political systems that affect education, but also include the philosophy behind their educational models and architectural models of these educational models (Karabey et al., 2000). In this context, it is believed that acting in accordance with the decisions made by educators and designers together in the design of school buildings; considering the physical environment in relation to the educational environment while planning; and dealing with the pedagogical aspect of the subject are necessary, thus with the success of the spatial setup, the cognitive, physical and emotional development of the children will be supported. For this reason, the study discusses Montessori education approach, which is used frequently in different countries in recent years and which characterizes the place as a lifeless instructor, and the educational environments in which this program is applied.

It is believed that the data generated are important in terms of using them in the creation of spaces to support the educational and social development of students. It is also thought that this is an interdisciplinary study owing to the fact that the education approaches, which are frequently taken from the pedagogical point of view, are evaluated from the design point of view in this study, so it is important in terms of contributing to the field of education and practice.

\section{RESEARCH METHOD}

In line with this purpose, a three-step method has been setup within the concept of study (Figure 1). First of all, the general characteristics of the Montessori educational approach were expressed and a literature review was conducted in this context. The second stage of the study is the phase that examined the spatial characteristics of the exemplar schools where the determined educational approaches are being implemented and which stand in the literature in this context. At this stage, the schools that the designers in various countries have planned in line with these principles are examined through plan planes and visuals. Because of limitations in the study, 7 example schools were included. At the last stage, as a result of the information obtained from the literature and school samples, the existence of some design decisions came to the forefront and the design approaches are schematically expressed in these titles. Thus, the relationship between educational approach and spatial setup has been revealed in the study.

A lot of pedagogical work has been conducted about the Montessori approach. The development of the approach, its general characteristics and the basic principles are covered in a wide range of studies. The purpose of this study is to examine the Montessori approach and the spatial decisions required by this approach. For this reason, general principles has been aimed to be mentioned briefly and to address primarily the principles that will influence spatial organization. However, it is possible to summarize these principles as the principle of the Montessori Method in general, as freedom of movement principle, free election principle, self-education principle, socialization principle (Durakoğlu, 2010).

In the early years of the twentieth century, educators such as M. Montessori and Reggio Emilia in Italy, R. Steiner in Central Europe, C. Freinet in France and J. Dewey in USA developed teaching and learning approaches 
different from each other. Within these approaches, the Montessori approach emerges as one of the most widely used educational approaches around the world.

The Montessori approach is an educational approach, born in Italy, unearthed by Maria Montessori (1870-1952), who earned the title of her country's first female medical doctor. In line with her view that the studies on educational philosophy in her lifetime are not sufficient in terms of educational quality, Montessori has provided a new educational approach. According to Montessori, education is a process in which parents, teachers, and children are in constant contact. In this process, not only the adult is helping the child but also the child is helping the adult (Schafer, 2006).

Montessori founded her first school in Rome in 1907. This school is a full-day program that serves 4-7 years old children of low-income families (Aydin, 2006). In the years of 1922-1943, the party, which Mussolini founded closed down all the democratic institutions in Italy as well as the Montessori schools. After this period, Montessori had obtained the opportunity to promote her method abroad in many countries of the world. After long trips to various countries, including the Netherlands, Spain and India, Pollard (1996) stated that the Montessori Method became the world's most common method of education in a short span of time (Durakoglu, 2010)

The aim of Montessori education is to raise citizens who are open to lifelong learning, are problem-solvers, selfdirected, talented, responsible and harmonious, and in this context to approach the child as an individual. The Montessori Method, which attaches importance to the physical and mental needs of the child, opposes the education to be made according to a predetermined program (Montessori 1953, 8-12). According to this approach, the teacher is only an observer and a timely interventionist, prepares the environment, directs the activity and provides stimulation to the child (Goffin, 2001). The child chooses to work according to his or her interests, does what he or she wants to do, teaches himself or herself, and becomes aware of his or her own freedom (Aydin, 2006). As their talents increase, they develop a strong sense of independence and self-confidence in the end.

Montessori (1932) argues that without freedom, personality cannot ideally develop. The "freedom" principle in the Montessori approach is expressed by Montessori as "the shortest and most concise explanation of the method we have implemented, giving children freedom in a pre-prepared environment" (Montessori, 1997). In order for a child to fully develop his or her physical, mental and spiritual potential, the child must be free (Aydin, 2012). For this reason, the first objective of education for Montessori is the child's self-discovery and liberation. Montessori sees the 'self-education' principle as a principle that allows the child to be liberated, and aims to bring the potential available in children to the highest, and expresses that it is appropriate for the child's natural growth and development (Mallory, 1989).

Highlighting the emancipation of the child as a basic principle, Montessori emphasizes that the educational environment must be of a quality that allows children to use their freedom (Bartolemeis, 1973). In Montessori education, the environment is a lifeless teacher and the child learns by constantly being stimulated in this environment (Montessori, 1950).

In the Montessori approach, the key phrase is the prepared environment. The approach is based on the child's development of his or her individual characteristics within the "prepared environment" (Orem, 1970). Montessori, (1972), refers to the prepared environment in the schools by the concepts of freedom, order, beauty and atmosphere, educational materials, community life, reality and nature (Jesus, 1987). Prepared environment is a modified environment that provides top level of opportunity for the child to explore and learn.

The Montessori approach is seen in general as an approach that attaches importance to the freedom of the child, provides the socialization of the child and makes the child feel important, and that is based on the child's selflearning, discovery and intertwining with the nature. In the second phase of the study, examples of schools are given that were designed based on these principles.

\section{MONTESSORI SCHOOL EXAMPLES}

The study was setup based on the existence of relationship between the general features of the educational approach and spatial setup. Within this setup, examples of schools, which stand in the literature and which were designed by the designers according to the Montessori philosophy, are examined (Table 1). In the plan plane and as a result of visual analyses, spatial analyses of these examples were carried out thus design criteria supporting the Montessori approach was revealed. 
Table 1. Schools Examined within the Scope of the Study

\begin{tabular}{lll}
\hline $\begin{array}{l}\text { Delft Montessori Okulu/1966/ } \\
\text { Netherlands }\end{array}$ & $\begin{array}{l}\text { Apollo Montessori } \\
\text { /1980/Netherlands }\end{array}$ & $\begin{array}{l}\text { Montessori College Oost/ } \\
\text { Schooo//2002/US }\end{array}$ \\
\hline School De Dijk/2009/ & $\begin{array}{l}\text { Fayetteville Montessori } \\
\text { ElementarySchool/2012 US }\end{array}$ & $\begin{array}{l}\text { Montessori School } \\
\text { Waalsdorp/2014/ Netherlands }\end{array}$ \\
\hline
\end{tabular}

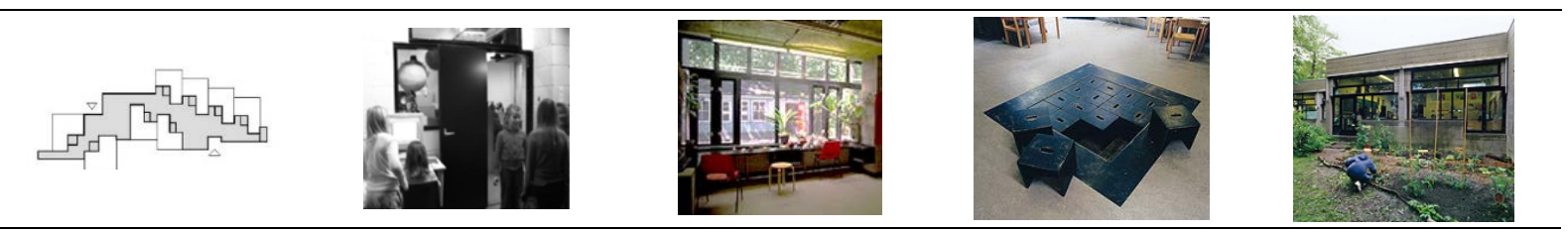

Figure 2. Delft Montessori School ${ }^{1}$

\section{Delft Montessori School}

Delft Montessori School was built in 1966, during the process in 1968, 1970, 1981, 2007 and 2009 with various additions and changes have come up to the day. Circulation areas are multi-purpose areas where different activities can be performed. This area "podium block", which is designed in connection with the classrooms, stands out. This block includes education, teaching, sitting, reading, playing, etc. It is a flexible base that allows different actions. Circulation can be narrowed and expanded in cases where it is obstructed and allows for different spatial arrangements. Classroom locations are in L form, and according to Hertzberger, this form provides flexibility by creating subspaces to support formal, informal and creative activities. Different activities are held at the two ends of the L classrooms and in the corner. Classrooms at the Delft school are thought of as house buildings on a street. The entrance halls between the street and the classroom are arranged to be able to function as pass-through-storage. In these places, niches were created for extracurricular activities. Small areas at the lower level in the entrance of the classrooms are areas where individual activities are carried out (Figure 2) (İslamoğlu, 2014).

\section{Apollo-Montessori and Willemspark Schools}

The Apollo schools are three-storey schools consisting of twin masses, Montessori School and Willemspark School. Both masses have the same exit point. The only difference between the two masses is the different orientation of the balconies in the classrooms due to their different location. A central hall surrounds the classrooms and this is the heart of the school. The passage areas between the classrooms and the corridor constitute individual, independent study areas. Apollo schools are designed as a large central hall that allows flexible spatial edits instead of corridors for activities that cannot be carried out in classrooms with small circulation areas. This hall is surrounded by four classrooms located on all floors of the school and is designed as a connection. The ladder in the hall constitutes the focal point of the school. The brown wooden ladder in this area is designed for children to carry out planned activities on the spandex side. This staircase is used for socialization, play, theatre, work, recreation and meeting purposes (Figure 3) (İslamoğlu, 2014).

${ }^{1}$ https://www.ahh.nl/index.php/en/projects2/9-onderwijs/114-montessori-school-delft (E.T. 12.04.2017) 

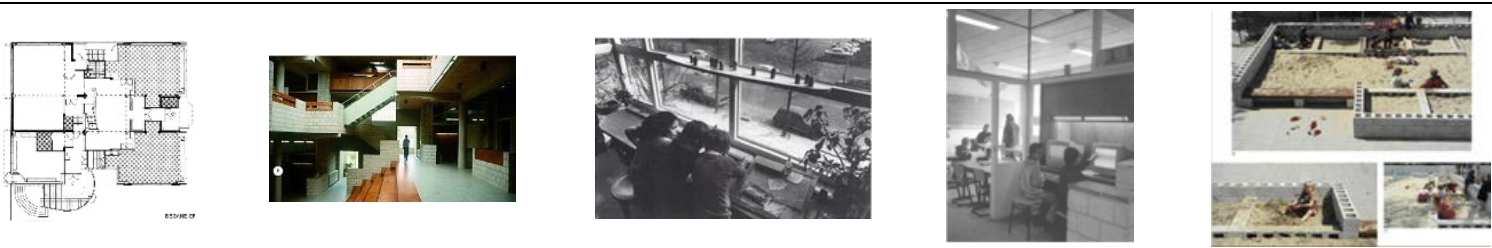

Figure 3. Apollo-Montessori and Willemspark Schools ${ }^{2}$

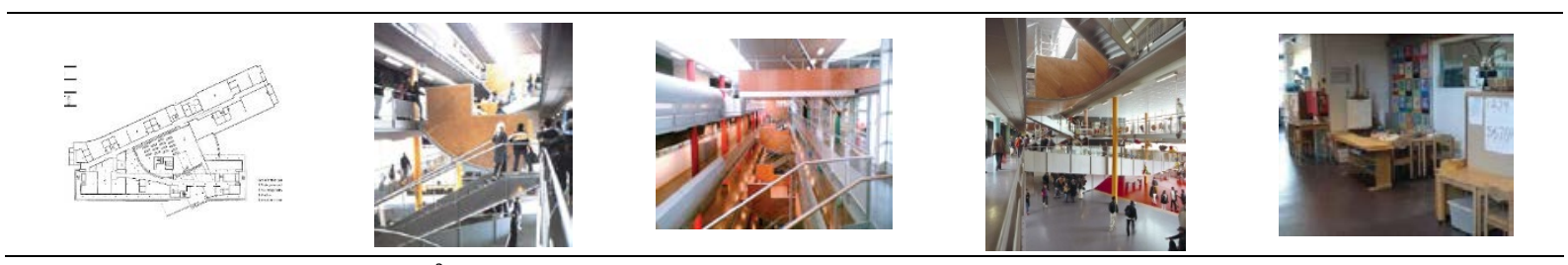

Figure 4. Montessori Oost School ${ }^{3}$

\section{Montessori Oost School}

The school is made up of twin masses, designed by Montessori's idea of encouraging children to learn by offering a wide selection with a clear structure. One of the masses is the school building and the other is the one that allows people to socialize and where the activities are carried out. Hertzberger's idea that schools must be like a small city with public spaces, squares, streets, and corridors prevails at this school, too. Areas where students can work individually or in small groups exist between corridors and classrooms. Between the two blocks, there is a space where the daylight can be taken to the central hall of the school. This two-story hall is an area that allows for different activities of the school. Every room in the school sees this central hall; for example, the teacher rooms open up to this space so what the students do during the recesses can be seen. The classrooms are separated from the corridors by large sliding doors, so the school is used as a large area. Corridors and classrooms allow students to work individually and in groups. School design aims to create a balance between supervision and confidentiality, to setup social equality and social equilibrium, and to enable all common areas to be used for informal activities (Figure 4).

\section{Henson Valley Montessori School}

The gathering of four masses that appear like villa forms the school. It has a plan that allows children to observe nature. An attempt was made to create a home like environment that allows students as much independence as possible. Light, openness, and connection to the outside world are the main themes shaping the design of the school. It is the focal point of the design of all classrooms to take in natural light, ventilate and be in nature. The whole school was arranged to connect with the outside world. Circulation area of the school is surrounded by coloured glass blocks and provides classes with natural reflection of light. This area is covered with patterns, flowers and rainbows, and was provided to represent the nature and the world. The classrooms in the kindergarten section of the school are open to the garden, allowing students to grow flowers, vegetables and fruits. Each class has a bathroom and a small kitchen. The goal is to convey the idea that students are talented and competent. The entire school has a natural flow that allows children to feel free while they are being protected. There are large windows in the classrooms. These windows are covered with glass bricks and allow natural light to enter in the form of different shapes. Glass bricks are painted by the students in their own colors and emphasize the feeling that the students have real possession of the place; and the painted edges encourage the students to look around in different shapes. With bright colors and furniture suitable for children, a warm and stimulating environment was created for the students in the school. Large size windows and a bright color palette stimulate curiosity and discovery for older students at the school (Figure 5).

\footnotetext{
2 https:/ / www.ahh.nl/index.php/en/projects2/9-onderwijs/113-apollo-schools (E.T. 04.03.2017)

${ }_{3}^{3}$ https://www.ahh.nl/index.php/en/projects2/9-onderwijs/55-montessori-college-oost-amsterdam (Date of Access $04.15 .2017)$
} 


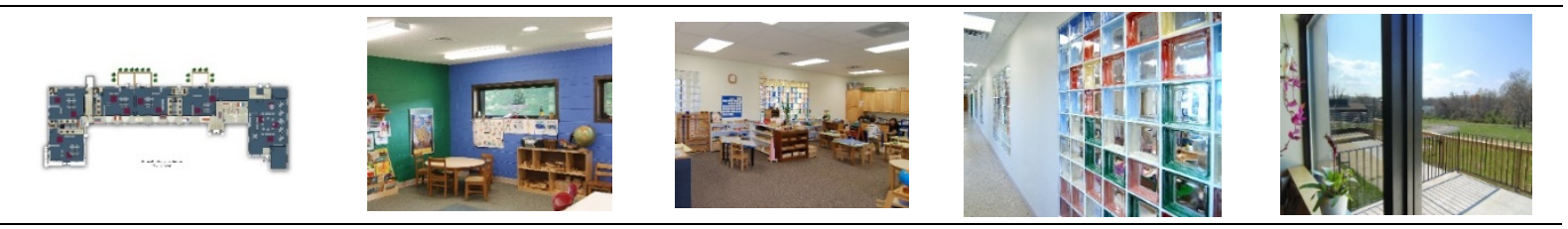

Figure 5. Henson Valley School ${ }^{4}$

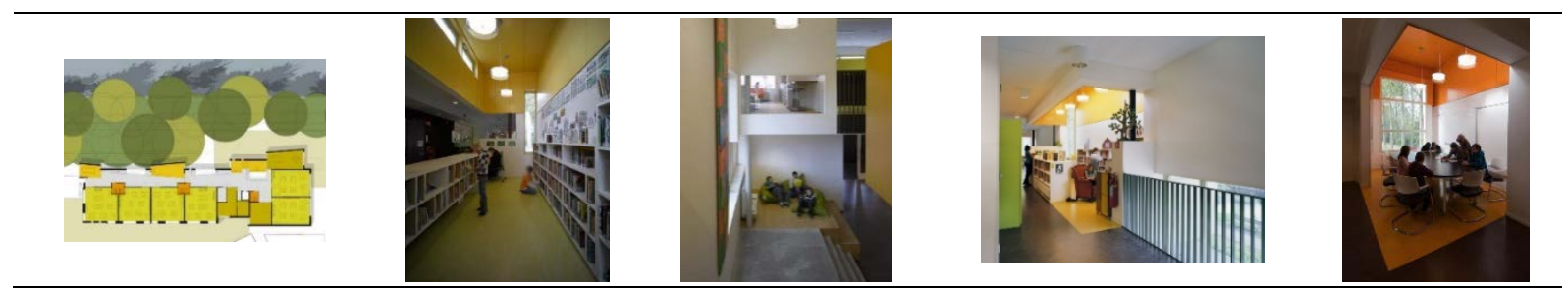

Figure 6. De Dijk School ${ }^{5}$

\section{De Dijk School}

The school has a mass setup with horizontal planning that is formed by cubic modules' coming together. It is the large window openings that attract the most attention in the massive setup. These openings were designed to enable students to communicate with nature. The school resides in a green area surrounded by water channels. This channel creates the spatial setup of the school. A backbone was planned according to this channel; a circulation area was created along this channel and all the spaces were connected to this spine. Various areas, such as classrooms, library and teacher's room, are shaped by this backbone. In the pockets opened on the backbone, units such as a library and a study area with an open plan type where students can work together, read books, and socialize at the same time were formed. Additionally, in the central backbone, an 8-meter-wide staircase stands out; and this staircase is used for multiple purposes as per spontaneously emerging events. Thanks to the openings created in the floor, a visual connection is established between this staircase and the upper floor. Each classroom has its own wet volume. Classrooms can open to the garden and students are free in these areas. The facade is white in color. The reason for choosing white color is to contrast with the black, gray-brown colors of the surrounding buildings and create a new beginning. The other side of the school is covered with a wooden floor, which is a warm material (Figure 6).

\section{Fayetteville Montessori School}

The school, which has a triangular plan that forms classrooms, a conference room and a canteen, is located on a green area in a wide-open space. The school has been provided with plenty of natural light, so care has been taken for the school to be one that invites students. The material used on the facade is simple, durable and economical to provide warmth and invitation. The school allows students, families and teachers to explore the relationship between the built environment and the natural environment. Care has been taken to ensure that the classrooms allow for calm and sensory experiences (interaction with smells, sounds, textures and the space). There is more than one teacher in the classrooms and the teachers are obliged to provide independent learning of the students without irritating. Classrooms are in relationship with the garden. Classrooms located on the ground floor can be opened to the garden. Each classroom has its own sink (Figure 7).

${ }^{4}$ http:/ / www.designshare.com/index.php/projects/henson-valley-montessori-school/intro (Date of Access 04.06.2017)

${ }^{5}$ http:/ / www.archdaily.com/94093/school-de-dijk-drost-van-veen-architecten (Date of Access 04.05.2017) 


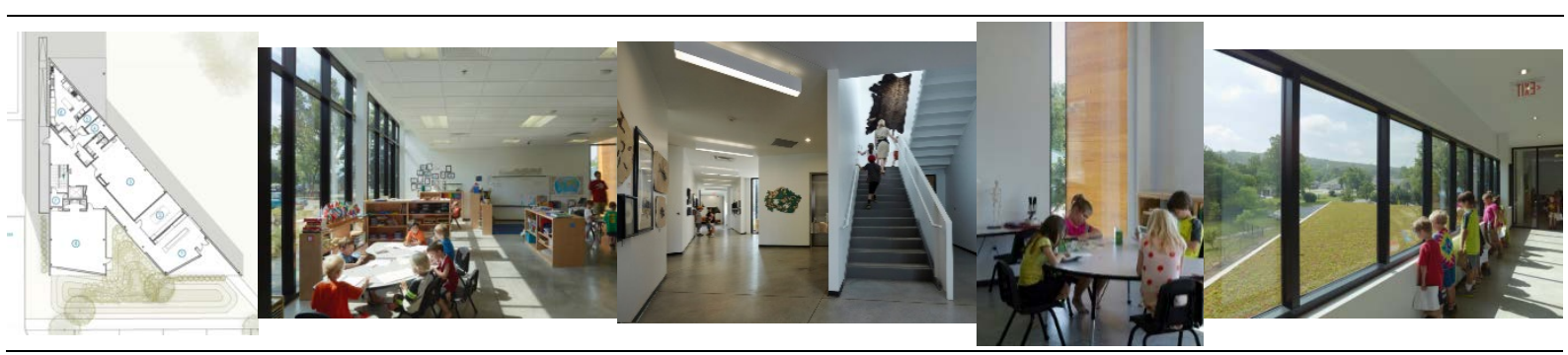

Figure 7. Fayette Montessori School ${ }^{6}$
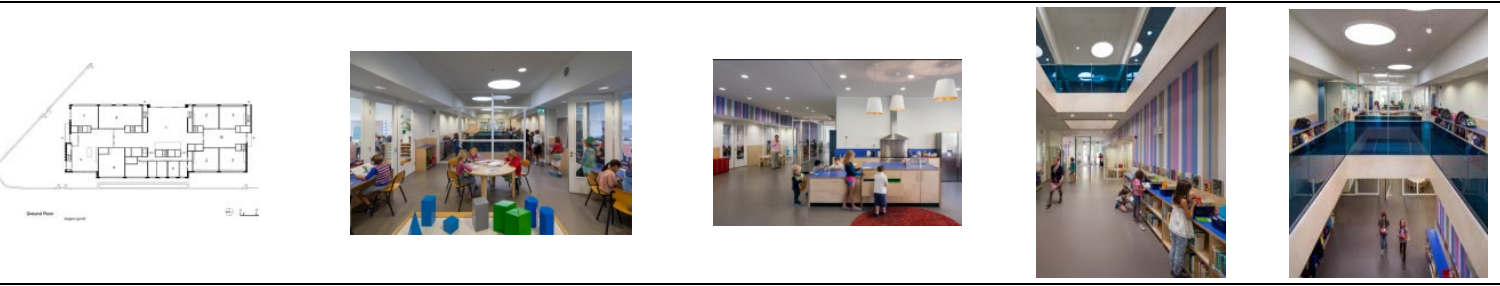

Figure 8. Waalsdorp Montessori School ${ }^{7}$

\section{Waalsdorp Montessori School}

The school offers dynamic training opportunities with its extensive and flexible internal structure for the Montessori education system. Two historic Linden trees and the entrance corner define the position of the school on the plot; this orientation provides the school with a welcome area and a large background area. The facade was built with strong profiles, covered with large bricks. These large and vertical bricks define the entrance. It was designed in a non-traditional arrangement the Montessori education requires. The main building consists of three units, each of which hosts a private group. Each unit has its classrooms, multi-functional corridors and entrance. The auditorium is the heart of the building. Depending on the pedagogical goals of the Montessori system directly, all these properties are interconnected by a wide variety of functional "streets" that function as meeting places where children can work together and play music together. The two floors are connected by three spaces, allowing daylight to enter the building's deep areas. The school has an open, transparent and flexible character. The service areas are integrated into spatial setup. In addition, importance was given to the selection of interior and exterior materials and wood-based materials were preferred depending on the Montessori approach (Figure 8).

\section{FINDINGS}

In the scope of the study on spatial effects of educational philosophies, 7 schools with Montessori approach were examined and some common design decisions were determined as a result of deliberations. In Montessori schools, these design decisions have been defined as design, interior-exterior relation, multipurpose circulation areas, flexible classrooms, visual linkage and natural light in children's schools and these decisions are explained and supported by schematic expressions.

\section{Child-Scale Design}

The student is in constant contact with the learning venue at the Montessori schools. The space design should be prepared according to the student and the equipment in the learning environment should be shaped according to the child who is the real owner of the environment. In these schools there is no equipment for teachers and it is the personality of the child that shapes it, not the authority of the adult (Standing, 1957). In all of the schools studied, there is the feeling that this place is completely owned by the children and it is special to them, thanks to the low-floor masses horizontally and the child-scale design approach in the equipment. This approach supports Montessori's thinking that the child lives the feeling of being at home, and needs to feel as comfortable and secure as at home. In addition, in these schools horizontal planning and low-floor masses are preferred in order to ensure

6 http://www.archdaily.com/776191/fayetteville-montessori-elementary-school-marlon-blackwell-architect (Date of Access 04.22.2017)

7 http://www.archdaily.com/560373/montessori-school-waalsdorp-de-zwarte hond/54486b75e58ece99970001d1-montessorischool-waalsdorp-de-zwarte-hond-photo (Date of Access 04.18.2017) 


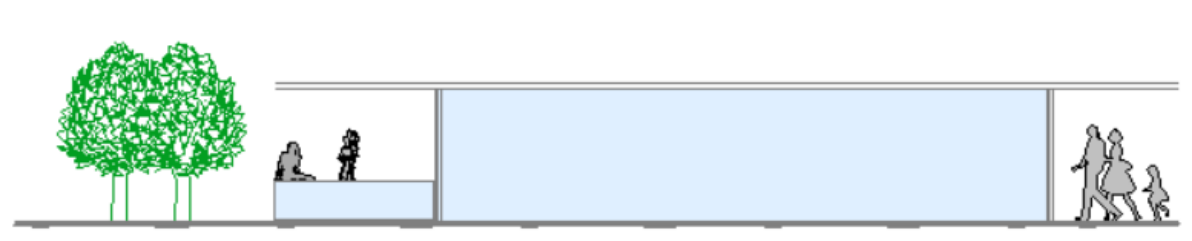

Figure 9. Child-Scale Design

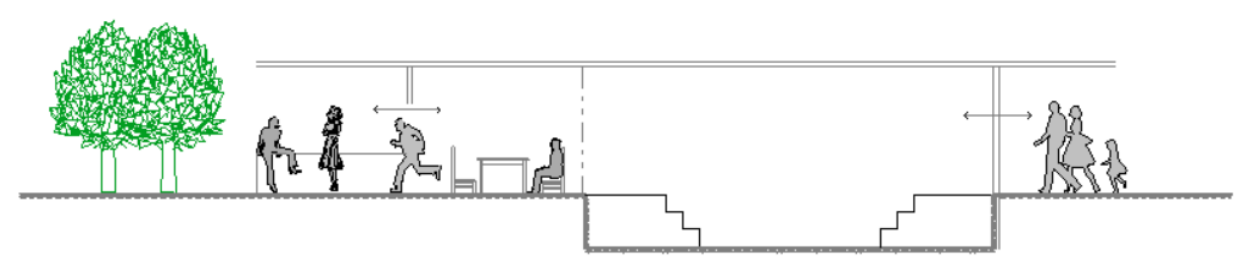

Figure 10. Internal-External Relationship

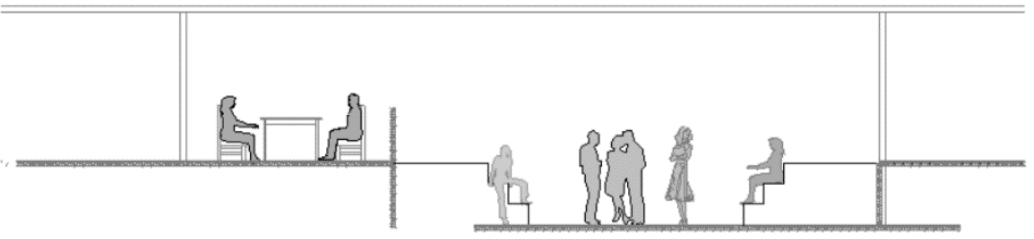

Figure 11. Multi-Purpose Circulation Areas

the social indiscrimination and equality between adults and children required by the educational approach (Figure 9).

\section{Internal-External Relationship}

The philosophy of Montessori gives great importance to nature and environment. For this reason, all schools are intertwined with nature, and there is a strong relationship between interior space and environment. In the Montessori classrooms, children are free to go out of school into the field (Sivri, 2014). Parallel to the importance given to nature, the internal-external relationship is provided by verandas, porches, fringes, inner and outer gardens, inner courts and winter gardens where the outdoor activities can be carried out in the Montessori education, and the activities held inside are also continued outside. In addition, spaces where outdoor natural events can be perceived from inside are designed (Figure 10).

\section{Multi-Purpose Circulation Areas}

Montessori philosophy attaches great importance to socialization, communication and interaction. In this context, the circulation areas in the schools are setup as multipurpose fields that constitute the heart of the school. It is aimed at the design of these areas to see a model of the social environment in which children live and will live in the future and to prepare for their future life. For this reason, corridors are not only the areas where the units merge and areas that are walked, but also the places with natural light and with the quality of a learning street where students from different age groups can socialize, rest, study and teach each other some things, and areas where spontaneously developing activities can be performed. The stairs in these areas are used as areas where students come together and socialize by carrying out many activities. Montessori argues that schools should be like children's home. For this reason, the use of wood, as a warm material, appears to be important in these areas (Figure 11).

\section{Flexible Classrooms}

According to Montessori, activity is important for the development of the child, and physical activity has an important role in mental development (Montessori, 1975). According to him, the child's intelligence evolves by motion. In the Montessori approach, additionally, the elimination of the need for a precisely tailored program and the fact, too, that students from different age groups perform many different activities at the same time make the designed spaces in these schools constantly changeable according to daily activities and needs. Montessori's space 

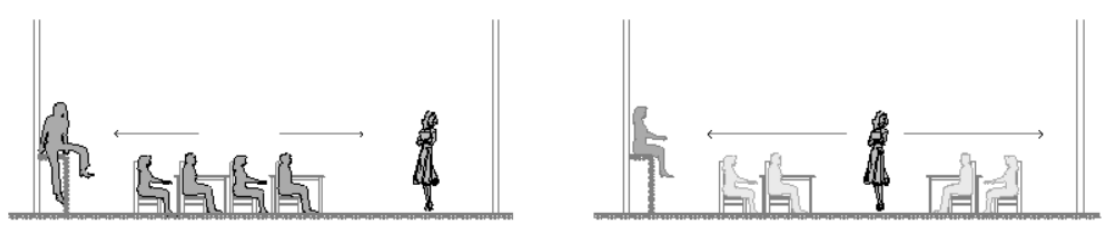

Figure 12. Flexible Classrooms
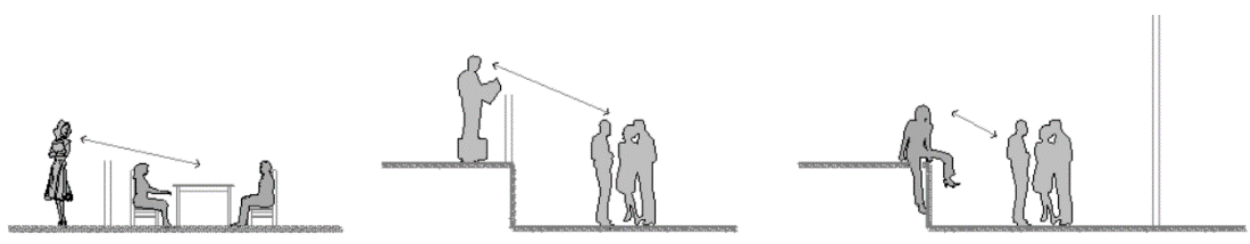

Figure 13. Visual Connection

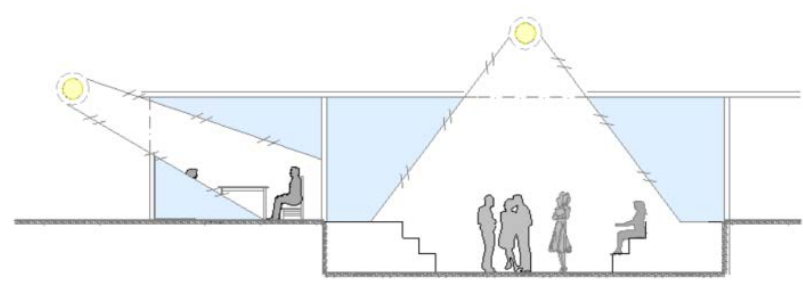

Figure 14. Natural light

approach facilitating motion and activities finds response with flexible spatial setups throughout all the schools studied. It is seen that particularly in classrooms, students have their special areas where their small or large group activities can take place, which provide students with a choice area and support their freedom, and where they can stay alone when needed. Flexibility in classrooms is important in terms of educational performance. It is expected that these spaces will be flexible enough to support change, activity, exploration, individual and group work according to different learning methods (Islamoğlu, 2014). In this context, education, for which all areas are designed as a learning field, also takes place outside the classrooms. Flexible classrooms with completely openplan that can open to the outside and inside in various shapes were designed. The classrooms are divided into subspaces so that they can provide individual and collective activities. The niches and subspaces created in these areas are areas where different activities can be carried out flexibly. In addition, it is observed that there are no closed school unit in all the schools; all the classrooms are in contact with the circulation areas and areas for common use; and the learning takes place in every place of the school (Figure 12).

\section{Visual Contact}

Inter-venue visual communication in Montessori schools also is another design criterion. The Montessori approach attaches importance to learning by seeing and communication. In this direction, there is a strong visual link between the entrances and other spaces throughout the schools. With the use of the partial separators and transparent boundaries between the entrance, the classrooms and the activity areas, spaces were designed allowing different age groups to see each other and letting them to be in visual contact with each other, and thus enabling exploration and communication, providing collaboration, and supporting socialization (Figure 13).

\section{Natural Light}

Natural light is important in the Montessori approach (Montessori, 1964). It is seen that great importance has been given to all examined schools' getting natural light and that the planning of some schools seems to be completely in this direction. It is seen that all the facades are designed to have natural light and that the roof openings that support it are used. It is seen that the power of natural light to gather people together was integrated into the design, and areas that are warmer and supportive of socialization were created (Figure 14). 


\section{CONCLUSION AND RECOMMENDATIONS}

It is seen that the effect of the Montessori approach on the educational spaces is very clear in the schools examined and that the space design supporting this approach should be evaluated pedagogically as well as architecturally.

In this context, it is believed that in the design of the school buildings, it is necessary to take action based on the decisions made by educators and designers together, to think about the physical environment qualities in relation to the educational approach to be applied, and to take the pedagogical direction of the subject into consideration; and thus the cognitive, physical and emotional development of the children will be supported with the success of the created spatial design. The study bears significance as it unearths the criteria that can be data in the field of education and practice by reflecting the presented design decisions of the Montessori schools and the educational needs of this approach in connection with the spatial requirements.

\section{REFERENCES}

Aydın, İ. (2012). Alternatif okullar. Ankara, Türkiye: Pegem Akademi, 60-61.

Bartolomeis, D. F. (1973). Maria Montessori e la pedogogia scientifica. Floransa: La Nuova Italia Editrice.

Chan, T. C. (1988). The aesthetic environment and student learning. School Business Affairs, 54(1), 26-27.

Durakoğlu, A. (2010). Montessori metodunda okuma ve yazma eğitimi. Aile ve Toplum, 11/5(20).

Goffin, S., \& Wilson, C. (2001). Curriculum models and early childhood education appraising the relationships. New Jersey: Prentice Hall.

İslamoğlu, Ö. (2014). A Method Suggestion for Determination of Flexibility Strategy in Schools (PhD Thesis). Trabzon: Karadeniz Technical University, Institute of Science and Technology.

Jesus, D. R. (1987). Design guidelines for montessori schools, Center for Architecture and Urban Planning Research Books, Milwaukee, 28

Karabey, H., \& Erkılıç, M. (2000). Eğitim felsefeleri ve okul yapıları. XXI Mimarlık Kültürü Dergisi, 03, 72-76.

Mallory, T. (1989). Montessori ve çocuğunuz, ana-babanın el kitabı (Trans: Füsun Öztaş ve Cihan Gülten). Ankara. Hatiboglu Yayinevi, 88.

Montessori, M. (1950). La scoperta del bambino. Roma: Garzanti, 114.

Montessori, M. (1932). Educazione e pace. ginevre: Bureau İnternational d'Education, 155.

Montessori, M. (1953). La mente del bambino. Roma: Officine Grafiche Aldo Garzanti. 8-12.

Montessori, M. (1964). Spontaneous Activity in Education, Robert Bentley Inc.

Montessori, M. (1975). Çocuk eğitimi. (Trans: Y. Güler). İstanbul: Sander Yayınları.

Montessori, M. (1997). Çocuk Eğitimi, Montessori Metodu. (Trans: Güler Yücel), 5. Eds., İstanbul: Özgür Yayınları, 224 ,

Orem, R. C. (1970). Montessori, her method and the movement. New York: Capricorn Books, 121.

Pollard, M. (1996). Maria Montessori. (Trans: Leyla Onat). Ankara: İlk kaynak Kültür ve Sanat Ürünleri.

Schafer, C. (2006). Ömür Törpüsü mü? Bal Küpü mü? (Trans: Ceyda Aydın). İstanbul: Sistem Yayınc1lı, 30-31.

Sivri, H. (2014), Okul Öncesi Eğitime Farklı Yaklaşımlar: Montessori ve Reggio Emilia, Ege Mimarlık, 52-57.

Standing, E. M. (1957). Maria Montessori: Her Life and Work, New York: Plume, 263-280.

\section{http://www.ejmste.com}

